\title{
Health Infrastructure and Health Indicators: The Case of Andhra Pradesh, India
}

\author{
T. Subba Lakshmi ${ }^{1}$, Dukhabandhu Sahoo ${ }^{2}$ \\ ${ }^{1}$ (PhD Scholar, School of Humanities, Social Sciences and Management, IIT Bhubaneswar, Bhubaneswar 751 \\ 007, Odisha, India. \\ ${ }^{2}$ (Assistant Professor, School of Humanities, Social Sciences and Management, IIT Bhubaneswar, Bhubaneswar \\ 751 007, Odisha, India.
}

\begin{abstract}
The paper calculates the elasticity coefficients of health indicators with respect to health infrastructure of the state of Andhra Pradesh, India during 1980-2010. A health infrastructure index is developed using health inputs like number of hospitals and dispensaries, number of beds and number of doctors in government hospitals. Double log simple regression model is used to estimate elasticity coefficients. The empirical result shows that the elasticity coefficients of health indicators like crude birth rate, crude death rate, infant mortality rate and life expectancy at birth with respect to health infrastructure are -37.966, -27.816, 30.598 and 10.282 respectively. Values of $R^{2}$ confirm that 70 percent of the variation in all most all health indicators is explained by health infrastructure. Thus, public health facilities are crucial for meeting the basic health requirements of masses in the state.
\end{abstract}

Key Words - Health Indicators, Health Infrastructure, Simple Regression Model

JEL Codes: 1150,118, C10

\section{Introduction}

In the pursuit of achieving of economic development, provision of infrastructure, both in quantity and quality said to play a pivotal role. It is suggested that infrastructure supports the processes of growth on which much of poverty reduction depends and also helps the poor access basic services which can improve their lives and income opportunities. To be specific, infrastructure can create a virtuous cycle through the provision of services leading to growth and then poverty reduction and again provision of services and so on [1]. There are several studies that establish positive impact of infrastructure on economic growth and productivity [2]; [3]; [4]; [5]. There are, however, attempts and evidences of infrastructure facilities improving the quality of life [6]; [7], health and educational attainments [8], and regional development [9].

Infrastructure is defined as "physical framework of facilities through which goods and services are provided to the public" [10]. Economists have introduced this term into the literature of development economics to use it interchangeably with 'Social Overhead Capital' [11] which results in facilities and services, and is usually provided free or at subsidised charges to the direct users. The World Development Report (WDR) 1994, which treats infrastructure as an "umbrella term" encompassing activities that share technical features such as economies of scale and spill over effects from users to non-users [12].

The infrastructure required in accelerating the pace of economic development constitutes both economic and social elements. The economic infrastructure is that which directly facilitates the production process. Transport, communication, energy, irrigation, banking etc. are the services comprising of economic infrastructure. The social infrastructure, on the other hand, has an indirect impact on the production process by developing an efficient and productive human resource. It includes education, health, housing, water supply, sewage disposal, sanitation etc. All these help in the attainment of higher growth and also improvement in the quality of life of the people as well. To argue in favour of the latter, it can be stated that better transport and communications provide improved access to health services. Electrification improves the quality of life including health services. Especially, social infrastructure has a much prominent role to play as compared to its counterpart.

Health outcomes like Life Expectancy at Birth (LEB), Crude Birth Rate (CBR), Crude Death Rate (CDR), Infant Mortality Rate (IMR), eradication of Malaria, Leprosy, Small Pox, Polio, Tuberculosis et cetera are greatly influenced by the availability of health infrastructure. Leipziger, et al.,( 2003)[13] emphasised the role of infrastructure in achieving three health related Millennium Development Goals. They found that apart from traditional variables (income, assets, education and direct health interventions), better access to basic infrastructure services has an important role to play in improving child health outcomes. Ghei, et al., (2010)[14] found positive association between child immunization and availability of health infrastructure. Datar, Mukherji and Sood (2007) [15] showed that the availability of health infrastructure had only a modest effect on immunization coverage. Larger and better-equipped facilities had bigger effects on immunization coverage. 
Health infrastructure in terms of hospitals, hospital beds, doctors, nurses, pharmacists et cetera has a significant direct and positive contribution to health outcomes of any country. It is observed from the health research literature that little attention has been paid by the researcher, policymakers, health personnel and government officials on the importance of health infrastructure[16] .

Health infrastructure is an important indicator to understand the health care delivery provisions and mechanisms in a region. It signifies the investments and priority accorded for creating the infrastructure in public and private sectors. In this connection, the paper is a modest attempt to calculate the elasticity coefficients of health indicators with respect to health infrastructure of the state of Andhra Pradesh, India. To keep the analysis simple and moderately reflect the above association, one progressive state has been selected.

\section{Hypothesis}

The hypotheses of the study are: (i) Health infrastructure does not affect crude birth rate; (ii) Health infrastructure does not affect crude death rate; (iii) Health infrastructure does not affect infant mortality rate; and (iv) Health infrastructure does not affect life expectancy at birth in the state.

\section{Assumptions}

The study is based on the following assumptions:

1. Health infrastructure indicators are subdivided into educational infrastructure and service infrastructure. The study considers service infrastructure only. Health of the people largely depends upon the number of hospitals and dispensaries, number of beds and number of doctors available in government hospitals. The paper assumes that these three components are important indicators of health infrastructure, keeping other components constant. Because, they have a special significance particularly to the poor and the marginalised, who cannot afford treatment in private hospitals/nursing homes;

2. Health infrastructure is positively related to health outcomes. It means more and more health infrastructure improves health outcomes; and

3. Available health infrastructure should be efficiently utilized to avoid wastage for better health outcomes.

\subsection{Research Setting and Data Sources}

\section{Methods}

The study is based on time series data, conducted in Andhra Pradesh, India in 2012. The sample observations are 30 years. The reference period of the study is 1980-2010. The required data collected from Statistical Abstracts of Andhra Pradesh, Various Issues, Directorate of Economics and Statistics, Hyderabad, Andhra Pradesh. Health Information of India, Ministry of Health and Family Welfare, Government of India, New Delhi; Sample Registration System (SRS) Bulletins', Census of India etc.

\subsection{Definition of Variables}

The definition of variables includes health infrastructure, namely number of hospitals and dispensaries, number of beds and number of doctors available in government hospitals (Allopathic). The crude birth rate indicates the number of live births occurring in a year per 1000 of the population. The crude death rate indicates the number of deaths occurring in a year per 1000 population. Infant mortality rate is expressed as the number of infant deaths per 1000 live births in a year. Life expectancy at birth indicates longevity of the people. It is expressed as the number of years a person may be expected to live when he/she is born, given the prevailing mortality rates in the population.

\subsection{Statistical Analysis}

This section discusses econometric methodology used in the paper. The paper calculates the elasticity coefficients of health indicators (CBR, CDR, IMR, LEB) with respect to health infrastructure of the state of Andhra Pradesh using double log simple regression model. The double log simple regression model is as follows: $\ln Y=\alpha+\beta \ln X+\varepsilon$ where, the estimate of $\beta$ gives the elasticity of $Y$ with respect to $X$. So here $Y$ will be CBR, CDR, IMR, LEB and $X$ will be health infrastructure index.

A health infrastructure index is developed taking into account number of hospitals and dispensaries, number of beds and number of doctors as latent variables using Principal Component Analysis (PCA) ${ }^{1}$. This index is used as an indicator for infrastructure (Independent Variable) in the model.

\footnotetext{
${ }^{1}$ PCA is a multivariate statistical technique used to form a new variable from an existing set of variables. The new variable contains as much variability as the initial variable. It helps to handle data more easily. In mathematical terms, from an initial set of $\mathrm{n}$ correlated variables, PCA creates uncorrelated indices or components, where each component is a linear weighted combination of the initial variables. For example, from a set of variables $\mathrm{X}_{1}$ through to $\mathrm{X}_{\mathrm{n}}$,
} 
Health Infrastructure Index

A health infrastructure index is constructed for health infrastructure as a weighted average of various components. It should be noted that health infrastructure components are not mutually uncorrelated. Pair wise correlations between them are given Table 1. Since there exist correlation between these components, it is not appropriate to pick one of the components (say number of hospitals or number of doctors) to analyse the effect of changes in them on health indicators. There is need to compute a "composite index" by combining various components of health infrastructure in a suitable way (assigning appropriate weights to different components) and relate it to the health indicators.

TABLE 1: Correlation Matrix

\begin{tabular}{|l|l|l|l|}
\hline $\begin{array}{l}\text { Components of Health } \\
\text { Infrastructure }\end{array}$ & $\begin{array}{l}\text { Number of Hospitals and } \\
\text { Dispensaries }\end{array}$ & Number of Beds & 0.192 \\
\hline $\begin{array}{l}\text { Number of Hospitals and } \\
\text { Dispensaries }\end{array}$ & 1.000 & -0.011 & 0.649 \\
\hline Number of Beds & -0.011 & 1.000 & 1.000 \\
\hline Number of Doctors & 0.192 & 0.649 & \\
\hline Source: Calculated and Compiled from Secondary Data \\
\hline
\end{tabular}

While constructing the health infrastructure index as a weighted average of various components, it is crucial to determine weights to be assigned to each of these components. The paper regards health infrastructure as a latent variable, which cannot be measured in a straight forward manner but is supposed to be linearly determined by various components. Suppose that we have three set of components, we can assume that the total variation in health infrastructure over years is accounted for by the variation in various components and error variance is negligible. The papers exploit the total variation in three components ${ }^{2}$ to arrive at the Health Infrastructure Index (HII).

For this purpose, we construct principal components (defined as normalised linear combinations) of various components which have the property that the first principal components $\left(\mathrm{P}_{1}\right)$ accounts for the largest proportion of total variation in all components, the second principal components $\left(\mathrm{P}_{2}\right)$ accounts for the second largest proportion of total variation in all components as the number of components, and so on. If we compute as many principal components as the number of components, the total variation in all components is accounted for by all principal components together. It is also true that the corr $\left(\mathrm{P}_{\mathrm{i}}, \mathrm{P}_{\mathrm{j}}\right)=0$, i,e the principal components are mutually uncorrelated. A weighted average of the principal components

$\mathrm{HII}=\lambda_{1} \mathrm{P}_{1}+\ldots \ldots \ldots \ldots+\lambda_{\mathrm{k}} \mathrm{P}_{\mathrm{k}} / \lambda_{1}+\ldots \ldots \ldots .+\lambda_{\mathrm{k}}$ defines the HII.

In the present case $\mathrm{k}=3$ and $\lambda_{1}>\lambda_{2}>\lambda_{3}$ are the successive eigen values of the $3 \times 3$ correlation matrix of observations on various components.

We assign largest weight $\lambda_{1} / \Sigma \lambda_{1}$ to $P_{1}$ because it accounts for the largest proportion of total variation in all components. Similarly, $\mathrm{P}_{2}$ has been assigned the second largest weight $\lambda_{2} / \Sigma \lambda_{2}$, because it accounts for the second largest proportion of the total variation in all the components and so on. The HII index can be expressed as a weighted sum of various components which provides weights (share) of individual components.

\section{A Brief Note On The Availability Of Health Infrastructure In India And Andhra Pradesh}

Promoting and protecting health is essential to human welfare and sustained economic and social development. This is recognized more than 30 years ago by the Alma-Ata Declaration signatories, who noted that Health for All would contribute both to a better quality of life and also to global peace and security. Since, independence, India is ostensibly driven by socialistic goals, has expressed its intention to discharge this responsibility in one-five-year plan after the other. Ambitious systems, programmes and schemes have been drawn up to alleviate poverty while promoting the goal of the universal healthcare. There is no doubt that India has achieved a good deal in health sector during the last 65 years. India has a huge Ministry of Health and

$\mathrm{PC}_{1}=\mathrm{a}_{11} \mathrm{X}_{1}+\mathrm{a}_{12} \mathrm{X}_{2}+\ldots . .+\mathrm{a}_{1 \mathrm{n}} \mathrm{X}_{\mathrm{n}}$

$\mathrm{PC}_{\mathrm{m}}=\mathrm{a}_{\mathrm{m} 1} \mathrm{X}_{1}+\mathrm{a}_{\mathrm{m} 2} \mathrm{X}_{2}+\ldots \ldots+\mathrm{a}_{\mathrm{nm}} \mathrm{X}_{\mathrm{n}}$

Where, $\mathrm{a}_{\mathrm{nm}}$ represents the weight for the mth principal component and the $\mathrm{n}$ variable. The variance of each component is given by the eigen values of the corresponding eigen vectors.

${ }^{2}$ Number of hospitals and bed strenghth are important indicators of healthcare facilities and number of doctors is the main indicator among all health human resources. 
Family Welfare at the centre and also in states. Government of India's (GOI) initiatives in the pubic health sector has recorded some noteworthy successes over time. Smallpox and Guinea Worm Disease have been eradicated from the country; Polio is on the verge of being eradicated; Leprosy and Filariasis can be expected to be eliminated in the foreseeable future.

India's fifth largest state by population and fourth largest state by area, Andhra Pradesh, which consist of 23 districts, 81 revenue divisions, 1128 mandals and 26613 villages, an area of 275,000 sq. km. and a population of 8.46 crore, has population density of 308 per sq. $\mathrm{km}$. (as against the national average of 364). The decadal growth rate of the state is $11.10 \%$ (against $17.64 \%$ for the country) and the population of the state is growing at a slower rate than the national rate. The literacy rate in the state is about $67 \%$ and is a cause for concern. The literacy rate in the state has gone up in recent years but is still below the national average of about $74 \%$. The sex ratio is above the national average at about 990 (See Table 2).

TABLE 2: Selected Demographic, Socio-Economic Indicators of Southern States

\begin{tabular}{|c|c|c|c|c|c|c|}
\hline State & $\begin{array}{c}\text { Total } \\
\text { Population } \\
\text { (Crore) } \\
(2011) *\end{array}$ & $\begin{array}{l}\text { Decadal } \\
\text { Growth } \\
\text { Rate } \\
(2011) *\end{array}$ & $\begin{array}{l}\text { Sex Ratio } \\
(2011) *\end{array}$ & $\begin{array}{l}\text { Literacy } \\
\text { Rate }(\%) \\
(2011) * *\end{array}$ & $\begin{array}{l}\text { Population } \\
\text { Living } \\
\text { Below } \\
\text { Poverty Line } \\
(\%)(2004- \\
05) * * *\end{array}$ & $\begin{array}{c}\text { Per Capita } \\
\text { Income at } \\
\text { Current } \\
\text { prices (Rs) } \\
(2008-09) \\
* * * *\end{array}$ \\
\hline Andhra Pradesh & 8.46 & 11.10 & 992 & 67.66 & 15.8 & 40902 \\
\hline Karnataka & 6.11 & 15.70 & 968 & 75.60 & 25.0 & 41513 \\
\hline Kerala & 3.33 & 4.90 & 1084 & 93.91 & 15.0 & 49316 \\
\hline Tamil Nadu & 7.21 & 15.60 & 995 & 80.33 & 22.50 & 45058 \\
\hline All India & 121 & 17.64 & 940 & 74.04 & 27.50 & 37490 \\
\hline \multicolumn{7}{|c|}{$\begin{array}{l}\text { Source: *Census of India, ** Economic Survey } 2011-12, * * * \text { Handbook of Statistics } 2010, * * * * \text { Andhra } \\
\text { Pradesh Economy in Brief 2011, Directorate of Economics and Statistics, Government of Andhra Pradesh, } \\
\text { Hyderabad, India. }\end{array}$} \\
\hline
\end{tabular}

Table 3, Table 4, Table 5 and Table 6 shows CBR, CDR, IMR and LEB across southern states. Both CBR and CDR in the state had fallen to low levels. The CBR is in line with the level for the country. LEB in Andhra Pradesh is lower when compared to other southern states and national average. IMR is an important component of mortality in general and a crucial factor in indicating health status. Unlike the crude death rate, IMR in Andhra Pradesh has always been lower than the all-India rate, but it was high when compared to other southern states. Though the IMR in the state declined from 106 in 1971 to 66 in 2001 and further declined to 53 in 2005. It is, however, a level that is unacceptably high. Moreover, the earlier sharp decline in IMR has not continued in the recent past. This situation has a bearing on the overall death rate and life expectancy at birth and is also indicative of the fact that the state has a long way to go before attaining transition in mortality. A cause of concern at this point for the state is how to achieve a further decline in the death rate when infant mortality remains high and stagnant.

TABLE 3: Crude Deaths Rates in Southern States

\begin{tabular}{|l|l|l|l|l|l|}
\hline $\begin{array}{l}\text { State } \\
\text { Year } \downarrow\end{array}$ & Andhra Pradesh & Karnataka & Kerala & Tamil Nadu & All India \\
\hline 1971 & 14.6 & 12.1 & 9.0 & 14.4 & 14.9 \\
\hline 1981 & 11.1 & 9.1 & 6.6 & 11.8 & 12.5 \\
\hline 1991 & 9.7 & 9.0 & 6.0 & 8.8 & 9.8 \\
\hline 2002 & 8.1 & 7.2 & 6.4 & 7.7 & 8.1 \\
\hline \multicolumn{5}{|l}{ Source: Andhra Pradesh Human Development Report, 2007 } \\
\hline
\end{tabular}

TABLE 4: Crude Birth Rates in Southern States

\begin{tabular}{|l|c|c|c|c|c|}
\hline $\begin{array}{l}\text { State } \rightarrow \\
\text { Year } \downarrow\end{array}$ & Andhra Pradesh & Karnataka & Kerala & Tamil Nadu & All India \\
\hline 1971 & 34.8 & 31.7 & 31.1 & 31.4 & 36.9 \\
\hline 1981 & 31.7 & 28.3 & 28.0 & 28.0 & 33.9 \\
\hline 1991 & 26.0 & 26.9 & 20.8 & 20.8 & 29.5 \\
\hline 2002 & 20.7 & 22.1 & 18.5 & 18.5 & 25.0 \\
\hline \multicolumn{6}{|l}{ Source: Andhra Pradesh Human Development Report, 2007 } \\
\hline
\end{tabular}


TABLE 5: Infant Mortality Rates in Southern States

\begin{tabular}{|l|l|l|l|l|l|}
\hline $\begin{array}{l}\text { State } \\
\text { Year } \downarrow\end{array}$ & Andhra Pradesh & Karnataka & Kerala & Tamil Nadu & All India \\
\hline 1971 & 106 & 95 & 58 & 113 & 129 \\
\hline 1981 & 86 & 69 & 37 & 91 & 110 \\
\hline 1991 & 73 & 77 & 16 & 57 & 80 \\
\hline 2002 & 62 & 55 & 10 & 44 & 63 \\
\hline 2005 & 57 & 50 & 14 & 37 & 58 \\
\hline Source: Andhra Pradesh Human Development Report, 2007 \\
\hline
\end{tabular}

TABLE 6: Life Expectancy at Birth in Southern States

\begin{tabular}{|c|c|c|c|c|c|c|}
\hline \multicolumn{2}{|l|}{$\begin{array}{ll}\text { State } & \rightarrow \\
\text { Year } & \downarrow\end{array}$} & $\begin{array}{l}\text { Andhra } \\
\text { Pradesh }\end{array}$ & Karnataka & Kerala & $\begin{array}{l}\text { Tamil } \\
\text { Nadu }\end{array}$ & All India \\
\hline \multirow[t]{2}{*}{$1996-2001$} & Male & 61.55 & 61.73 & 70.69 & 65.21 & 62.36 \\
\hline & Female & 63.74 & 65.36 & 75.00 & 67.58 & 63.39 \\
\hline \multirow[t]{2}{*}{ 2001-2006 } & Male & 62.79 & 62.43 & 71.67 & 67.00 & 64.11 \\
\hline & Female & 65.00 & 66.44 & 75.00 & 69.75 & 65.43 \\
\hline \multirow[t]{2}{*}{$2006-2011$} & Male & 63.92 & 63.10 & 72.00 & 68.45 & 65.63 \\
\hline & Female & 66.16 & 67.43 & 75.00 & 71.54 & 67.22 \\
\hline
\end{tabular}

In the health sector, health outcomes are not commensurate with the investment made. While timely access to quality and affordable health care, reduction in maternal mortality, infant and under 5 mortality, universal coverage under the T.B. control program, eradication of leprosy or containment of malaria and other infectious diseases continue to be problematic, the disease burden in 2015 on account of non-communicable diseases is also estimated to reach unsustainable levels [17]. NIMHANS study showed that illness continues to be a major cause of rural indebtedness. Chronic ill health was the second reason for the large number of suicides in rural areas of Andhra Pradesh during the years 2001-2003.

All health related aspects are influenced by the availability of and access to health services. Individual households and the state are the most important stakeholders in health services systems. To protect and promote general health, the public health infrastructure must be strong. A minimum level of physical infrastructure is needed to provide public services and also to increase access to health services. Table 7 shows number of hospitals, beds and dispensaries per lakh population cross Southern states. The number of hospitals per lakh population in Andhra Pradesh is more than that of Karnataka and Tamil Nadu as well as all India level. Whereas the number of beds, dispensaries are much lesser than other states and all India level. This needs attention of the government.

Table 7: Number of Hospitals, Beds and Dispensaries Per Lakh Population across Southern States 2002

\begin{tabular}{|l|l|l|l|l|l|}
\hline Particulars & Andhra Pradesh & Karnataka & Kerala & Tamil Nadu & All India \\
\hline Hospitals & 4.2 & 0.6 & 6.7 & 0.7 & 1.6 \\
\hline Beds & 65.5 & 79.4 & 255.1 & 87.5 & 69.1 \\
\hline Dispensaries & 0.4 & 1.7 & 6.4 & 0.9 & 3.0 \\
\hline Source: www.indiastat.com
\end{tabular}

According to the government's formula, we're supposed to have one sub-centre for every 5,000 people (3,000 in hilly areas), one primary health centre for every 30,000 people (20,000 in hilly areas) and one community health centre for every 120,000 people (80,000 in hilly areas). In this connection, Table 8 shows that Andhra Pradesh is far better with respect to the availability of Sub Centres (SCs), ANM at SCs, Health Assistant (Male) at PHCs, Doctors at PHCs, Obstetricians \& Gynaecologists' at CHCs, Nurse/Midwife at PHCs and $\mathrm{CHCs}$ as the actual is more than the required as per government formula. But it cannot tell us, for example, about whether the facilities are appropriately located and utilized. 
Table 8: Andhra Pradesh in a Comparative Framework

\begin{tabular}{|c|c|c|c|c|c|c|}
\hline Particulars & & $\begin{array}{l}\text { Andhra } \\
\text { Pradesh }\end{array}$ & Karnataka & Kerala & Tamil Nadu & All India \\
\hline \multirow[t]{3}{*}{ Sub-Centres } & Required & 11699 & 7369 & 4761 & 7057 & 158792 \\
\hline & In Position & 12522 & 8143 & 4575 & 8706 & 147069 \\
\hline & Shortfall & \begin{tabular}{|l|}
----- \\
\end{tabular} & ----- & 186 & ----- & 19590 \\
\hline \multirow{3}{*}{$\begin{array}{l}\text { Primary Health } \\
\text { Centres }\end{array}$} & Required & 1924 & 1211 & 4761 & 1173 & 26022 \\
\hline & In Position & 1570 & 2193 & 4575 & 1283 & 23673 \\
\hline & Shortfall & \begin{tabular}{|l|}
354 \\
\end{tabular} & ----- & 186 & ----- & 4252 \\
\hline \multirow{3}{*}{$\begin{array}{l}\text { Community Health } \\
\text { Centres }\end{array}$} & Required & 481 & 302 & 197 & 293 & 6491 \\
\hline & In Position & 167 & 325 & 233 & 256 & 4535 \\
\hline & Shortfall & 314 & ----- & ----- & 37 & 2115 \\
\hline \multirow{3}{*}{$\begin{array}{l}\text { Multipurpose Worker } \\
\text { (Female)ANM at Sub } \\
\text { Centres }\end{array}$} & Required & 12522 & 8143 & 4575 & 8706 & 147069 \\
\hline & In Position & 22140 & 8822 & 3418 & 8635 & 166202 \\
\hline & Shortfall & \begin{tabular}{|l|}
----- \\
\end{tabular} & ----- & 1157 & 71 & 10793 \\
\hline \multirow{3}{*}{$\begin{array}{l}\text { Health Worker (Male) } \\
\text { MPW(M) at Sub } \\
\text { Centres }\end{array}$} & Required & 12522 & 8143 & 4575 & 8706 & 147069 \\
\hline & In Position & 6127 & 3762 & 1285 & 959 & 52774 \\
\hline & Shortfall & 6395 & 4381 & 3290 & 7747 & 94337 \\
\hline \multirow{3}{*}{$\begin{array}{l}\text { Health Assistant } \\
\text { (Female)/LHV at PHCs }\end{array}$} & Required & 1570 & 2193 & 813 & 1283 & 23673 \\
\hline & In Position & 1564 & 2266 & 795 & 868 & 17034 \\
\hline & Shortfall & 6 & ----- & 18 & 415 & 7275 \\
\hline \multirow{3}{*}{$\begin{array}{l}\text { Health Assistant } \\
\text { (Male) at PHCs }\end{array}$} & Required & 1570 & 2193 & 813 & 1283 & 23673 \\
\hline & In Position & 1920 & 658 & 633 & 1895 & 16565 \\
\hline & Shortfall & \begin{tabular}{|l|}
----- \\
\end{tabular} & 1535 & 180 & ----- & 10029 \\
\hline \multirow{3}{*}{ Doctor at PHCs } & Required & 1570 & 2193 & 813 & 1283 & 23673 \\
\hline & In Position & 2214 & 3198 & 1122 & 2268 & 25870 \\
\hline & Shortfall & \begin{tabular}{|l|}
----- \\
\end{tabular} & ----- & ----- & ----- & 2433 \\
\hline \multirow{3}{*}{$\begin{array}{l}\text { Obstetricians \& } \\
\text { Gynaecologists at } \\
\text { CHCs }\end{array}$} & Required & 167 & 325 & 233 & 256 & 4535 \\
\hline & In Position & 260 & 233 & NA & 0 & 1939 \\
\hline & Shortfall & \begin{tabular}{|l|}
---- \\
\end{tabular} & 92 & NA & 256 & 2271 \\
\hline \multirow[t]{3}{*}{ Physicians at $\mathrm{CHCs}$} & Required & 167 & 325 & 233 & 256 & 4535 \\
\hline & In Position & 20 & 192 & NA & 0 & 1165 \\
\hline & Shortfall & 147 & 133 & NA & 256 & 2949 \\
\hline \multirow[t]{3}{*}{ Paediatricians at $\mathrm{CHCS}$} & Required & 167 & 325 & 233 & 256 & 4535 \\
\hline & In Position & 90 & 133 & NA & 0 & 1311 \\
\hline & Shortfall & 77 & 192 & NA & 256 & 2991 \\
\hline \multirow{3}{*}{$\begin{array}{l}\text { Total specialists at } \\
\text { CHCS }\end{array}$} & Required & 668 & 1300 & 932 & 1024 & 18140 \\
\hline & In Position & 480 & 726 & 774 & 0 & 6781 \\
\hline & Shortfall & 188 & 574 & 158 & 1024 & 11361 \\
\hline \multirow[t]{3}{*}{ Radiographers } & Required & 167 & 325 & 233 & 256 & 4535 \\
\hline & In Position & 65 & 51 & 10 & 98 & 1817 \\
\hline & Shortfall & 102 & 21 & 223 & 158 & 2724 \\
\hline \multirow[t]{3}{*}{ Pharmacist } & Required & 1737 & 2518 & 1046 & 1539 & 28208 \\
\hline & In Position & 1614 & 2054 & 1014 & 1159 & 21688 \\
\hline & Shortfall & 123 & 464 & 32 & 380 & 7655 \\
\hline \multirow{3}{*}{$\begin{array}{l}\text { Laboratory } \\
\text { Technicians }\end{array}$} & Required & 1737 & 2518 & 1046 & 1539 & 28208 \\
\hline & In Position & 1363 & 1344 & 268 & 870 & 15094 \\
\hline & Shortfall & 374 & 1174 & 778 & 669 & 14225 \\
\hline \multirow[t]{3}{*}{ Nurse/Midwife } & Required & 2739 & 4468 & 2444 & 3075 & 55418 \\
\hline & In Position & 4056 & 4309 & 3383 & 4287 & 58450 \\
\hline & Shortfall & 826 & 159 & ----- & ----- & 13683 \\
\hline
\end{tabular}

Source: RHS Bulletin, March 2010, Ministry of Health, Family Welfare, Government of India

It is clear from Table 8 that Andhra Pradesh is worst-off in many of its components of health infrastructure. There are wide differences between what she needs, and what is actually in place: she has only 1570 PHCs compared to the 1924 needed, which is a shortfall of 19 per cent; 167 CHCs compared to the 481 required (a shortfall of 65.29 per cent); 6127 Health Worker (Male) at Sub Centres compared to the 12522 (a 
shortfall of 47.87 per cent); 20 Physicians at CHCs compared to the 167 required (a shortfall of 88 per cent); 480 Total Specialists at CHCs compared to the 668 required (a shortfall of 28.4 per cent); 1614 Pharmacists at PHCs and CHCs compared to the 1737 (a shortfall of 7 per cent); 1363 Laboratory Technicians compared to the 1737 required (a shortfall of 21 per cent).

\section{Empirical Results and Its Discussion}

This section presents the results of empirical investigation. This part estimates elasticity coefficients of health indicators such as CBR, CDR, IMR and LEB with respect to health infrastructure (HI) . The estimated results are presented in Table 9.

Basic indicators of health like CBR, CDR, IMR and LEB give broad picture of health status of a country and state. They can be used to assess specific health care needs and also for evaluating quality of health services and programmes. Good health care facilities are essential for creating healthy citizens and society that can effectively contribute to social and economic development. The results (See Table 9) show that the elasticity of health indicators like CBR, CDR, IMR and LEB with respect to health infrastructure is -37.966, -27.816, 30.598 and 10.282 respectively. They indicate that 1 per cent increase in health infrastructure decreases CBR by 37.966 per cent, CDR by 27.816 per cent and IMR by 30.598 per cent respectively. Similarly, 1 per cent increase in health infrastructure increases LEB by 10.282 per cent. Values of $\mathrm{R}^{2}$ confirm that 70 percent of the variation in all most all health indicators is explained by health infrastructure. Thus, public health facilities are crucial for meeting the basic health requirements of masses in the state.

Table 9: Elasticity of Health Indicators with respect to Health Infrastructure: Double Log Simple Regression Result

\begin{tabular}{|c|c|c|c|c|c|}
\hline No. & $\begin{array}{ll}\text { Independent Variable } & \longrightarrow \\
\text { Dependent Variable } & \downarrow\end{array}$ & Constant & $\operatorname{lnHI}$ & $\mathrm{R}^{2}$ & $\mathrm{~F}$ \\
\hline 1 & $\operatorname{lnCBR}$ & $\begin{array}{c}79.112 \\
(\mathrm{SE}: 7.913 \\
\mathrm{t}: 9.998)\end{array}$ & $\begin{array}{l}-37.966^{*} \\
\text { (SE:3.956 } \\
\text { t:-9.596) }\end{array}$ & 0.767 & $97.467 *$ \\
\hline 2 & $\operatorname{lnCDR}$ & $\begin{array}{c}57.810 \\
(\mathrm{SE}: 6.028 \\
\mathrm{t}: 9.589) \\
\end{array}$ & $\begin{array}{l}-27.816^{*} \\
\text { (SE:3.014 } \\
\text { t:-9.228) } \\
\end{array}$ & 0.753 & $93.465^{*}$ \\
\hline 3 & lnIMR & $\begin{array}{c}65.417 \\
(\mathrm{SE}: 7.819 \\
\mathrm{t}: 8.366) \\
\end{array}$ & $\begin{array}{l}-30.598^{*} \\
(\text { SE:3.910 } \\
\text { t:-7.826) }\end{array}$ & 0.686 & $65.585^{*}$ \\
\hline 4 & $\operatorname{lnLEB}$ & $\begin{array}{c}-16.455 \\
(\mathrm{SE}: 1.957 \mathrm{t}:- \\
8.406)\end{array}$ & $\begin{array}{c}10.282 * \\
(\mathrm{SE}: 0.979 \mathrm{t}: 10.505)\end{array}$ & 0.798 & $111.389^{*}$ \\
\hline
\end{tabular}

\section{Summery and Conclusion}

The paper is an attempt to calculate elasticity coefficients of health outcomes with respect to health infrastructure in one of the progressive states of India, i.e., Andhra Pradesh, considering data set for the period 1980-2010. A health infrastructure index is developed using health inputs like number of hospitals and dispensaries, number of doctors and number of beds in government hospitals. The double log simple regression technique confirms that health infrastructure has significant and positive bearing on health indicators. Only building good health infrastructure does not yield good health outcomes. It largely depends on the operational efficiency, implementation, maintenance of health infrastructure, and the efficient utilization of the available infrastructure in the state.

\section{References}

[1] Government of Madhya Pradesh, Madhya Pradesh Human Development Report, 2007

[2] Straub, S., Infrastructure and Growth in Developing Countries: Recent Advances and Research Challenges, The World Bank Policy Research Working Paper 4460, 2008.

[3] Aschauer, D.A., Do States Optimise? Public Capital and Economic Growth, The Annals of Regional Science, 34(3), $2000,343-363$.

[4] Macdonald, R., An Examination of Public Capital's Role in Production, Research Paper Series 50, 2008,Economic Analysis Division, Statistics Canada.

[5] Devarajan, S., Swaroop, V. and Zou, H., What do Governments buy? The Composition of Public Spending and Economic Performance, Public Economic Working Paper Series 1082, 2008, Country Economics Department, World Bank, Washington DC.

[6] Baldwin, J. R, and Dixon, J., Infrastructure Capital: What is it? Where is it? How much of it is there? Research Paper Series 16, 2008, Economic Analysis Division, Statistics Canada. 
[7] Schauer, D.A., Public Capital and Economic Growth: Issues of Quantity, Finance and Efficiency, Economic Development and Cultural Change, 48(2), 1998, 391-406.

[8] Agenor, P. R., and Moreno-Dodson, B, Public Infrastructure and Growth: New Channels and Policy Implications, The World Bank Policy Research Working Paper 4064, 2008.

[9] Nijkamp, P., Infrastructure and Regional Development: A Multidimensional Policy Analysis, Empirical Economics, 11(1), 1986, 121.

[10] Khader, S.A., Productivity in Infrastructure, Yojana, 42(1), 1998,13-18.

[11] Youngson, A.J., Overhead Capital: A Study in Development Economics, (Edinburgh University Press, Edinburg, 1967$)$, p.13.

[12] World Bank, World Development Report: Infrastructure for Development, Washington DC and New York, The World Bank and Oxford University Press, 1994, p 2.

[13] Leipziger, D., M. Fay, Wodon, Q. and T. Yepes, Achieving the Millennium Development Goals: The Role of Infrastructure, Working Paper, No. 3163, 2003, World Bank, November.

[14] Ghei, K, Agarwal, S, Subramanyam, M.A., and Subramanian, S. V., Association Between Child Immunization and Availability of Health Infrastructure in Slums in India, The Archives of Pediatrics \& Adolescent Medicine, 164 (3),2010,243-249.

[15] Datar, A., Mukherji A. and Sood, N. Health Infrastructure and Immunization Coverage in Rural India, Indian Journal of Medical Research, 125, 2007, 31-42.

[16] Rout, H. S., Health Infrastructure in Orissa: An Inter-District Analysis, The Icfai Journal of Infrastructure, 5(4), 2007, 58-71.

[17] Government of Andhra Pradesh (2005): Task Force on Comprehensive Social Health Insurance Programme for Andhra Pradesh, Ministry of Health, Medical and Family Welfare Department, Hyderabad, Andhra Pradesh, India. 